\title{
Literature Review : Gambaran Pengetahuan Sikap Dan Perilaku Masyarakat Tentang COVID-19
}

\author{
M. Arzha Firmansyah ${ }^{1 *}$, Dian Kartikasari ${ }^{2}$, \\ ${ }^{1,2}$ Program Studi Sarjana Keperawatan, Universitas Muhammadiyah Pekajangan Pekalongan, \\ Indonesia \\ *email: arzhafir04@gmail.com
}

\begin{abstract}
The number of positive COVID-19 cases that continue to experience significant cases indicates that the distribution is still very high. The community is expected to carry out preventive behaviors. Domain consists of knowledge, attitudes and behavior. Based on previous research, people have good knowledge and behavior about COVID-19, while $50 \%$ have a positive attitude about COVID-19. The purpose of this study was to describe the knowledge, attitudes and behavior of the community about COVID-19. The design of this study is a literature review by accessing the basic data of Pubmed, DOAJ, Garuda and Google Scholar. The search for articles was conducted using a combination of keywords: knowledge of COVID-19, attitudes of COVID-19, practice of COVID-19, knowledge of COVID-19, attitudes about COVID-19 and behavior about COVID-19. The results showed that most of the respondents had good knowledge (80\%), good attitude (70\%) and good behavior $(90 \%)$ about COVID-19. The community needs to actively participate in efforts to prevent COVID-19 by increasing knowledge, attitudes and behaviors to prevent COVID-19.
\end{abstract}

Keywords: COVID-19; knowledge; attitude; behavior

\begin{abstract}
Abstrak
Jumlah kasus positif COVID-19 yang masih terus mengalami lonjakan signifikan menunjukkan bahwa persebaran masih sangat tinggi. Masyarakat diharapakan untuk melakukan perilakuperilaku pencegahan. Domain perilaku terdiri dari pengetahuan, sikap dan perilaku. Berdasarkan penelitian terdahulu, masyarakat memiliki pengetahuan dan perilaku yang baik tentang COVID-19, sementara 50\% memiliki sikap yang positif tentang COVID-19. Tujuan penelitian ini adalah untuk mengetahui gambaran pengetahuan, sikap dan perilaku masyarakat tentang COVID-19. Desain penelitian ini adalah literature review dengan mengakses basis data Pubmed, DOAJ, Garuda dan Google Scholar. Pencarian artikel dilakukan dengan kombinasi kata kunci: knowledge COVID-19, attitude COVID-19, practice COVID-19, pengetahuan tentang COVID-19, sikap tentang COVID-19 dan perilaku tentang COVID-19. Hasil penelitian menunjukkan mayoritas responden mempunyai pengetahuan yang baik (80\%), sikap yang baik $(70 \%)$ dan perilaku yang baik $(90 \%)$ tentang COVID-19.

Masyarakat perlu berpatisipasi aktif dalam upaya pencegahan COVID-19 dengan meningkatkan pengetahuan, sikap dan perilaku-perilaku pencegahan COVID -19 .
\end{abstract}

Kata kunci: COVID-19; Pengetahuan; sikap; perilaku

\section{Pendahuluan}

Jumlah kasus positif COVID-19 yang terus mengalami penambahan menunjukkan bahwa persebaran COVID-19 masih sangat tinggi. Penyebaran COVID-19 antar manusia menjadi sumber transmisi utama sehingga penyebaran menjadi lebih cepat dan agresif [1]. Untuk menghentikan persebaran COVID-19, masyarakat diharapkan melakukan perilaku-perilaku pencegahan seperti jaga jarak (social distancing), cuci tangan secara teratur menggunakan sabun dan air bersih, serta memakai masker [2]. 


\section{Prosiding Seminar Nasional Kesehatan 2021 Lembaga Penelitian dan Pengabdian Masyarakat Universitas Muhammadiyah Pekajangan Pekalongan}

Dalam menjaga kesehatan seseorang, terdapat dua faktor pokok yang memengaruhi kesehatan, yaitu faktor perilaku dan faktor non-perilaku. Menurut B. Bloom, terdapat tiga domain/ranah dari perilaku, yaitu pengetahuan (knowledge), sikap (attitude), dan perilaku (practice) [3]. Pengetahuan merupakan pemahaman seseorang tentang topik yang diberikan. Pengetahuan adalah kemampuan untuk menerima, mempertahankan, dan menggunakan informasi, yang dipengaruhi oleh pengalaman dan keterampilan [4].

Sikap merupakan respon atau reaksi seseorang yang masih bersifat tertutup terhadap suatu objek, stimulus, atau topik. Sikap juga dapat diartikan sebagai kecenderungan seseorang untuk bertindak, baik mendukung maupun tidak mendukung pada suatu objek. Sikap belum merupakan suatu tindakan, tetapi merupakan suatu faktor predisposisi terhadap suatu perilaku. Sikap yang utuh dibentuk oleh komponen kognisi, afeksi dan konasi [3]. Perilaku adalah segala kegiatan atau aktivitas yang dilakukan seseorang, sebagai reaksi atau respons terhadap stimulus dari luar, yang menggambarkan pengetahuan dan sikap mereka [4].

Berbagai penelitian telah membahas tentang pengetahuan, sikap dan perilaku masyarakat tentang COVID-19. Penelitian Erfani et al., (2020) menunjukkan sebagian besar responden mempunyai pengetahuan, sikap dan perilaku yang sedang tentang COVID-19 [5]. Sedangkan penelitian Moudy \& Syakurah, (2020) menunjukkan hasil penelitian yang berbeda yaitu sebagian besar responden memiliki pengetahuan dan perilaku yang baik tentang COVID-19, sementara separuh responden memiliki sikap yang positif tentang COVID-19 [4].

Pengetahuan masyarakat yang baik ditunjukkan dengan mampu menjawab pertanyaan tentang deskripsi umum virus SARS-CoV-2, gejala penyakit, penularan, faktor risiko, penyembuhan, pencegahan, dan bahaya COVID-19, serta etika saat batuk dan bersin, penggunaan masker, dan cara mencuci tangan. Sikap masyarakat responden yang positif ditunjukkan dengan memiliki sikap tenang, berhati-hati, dan meningkatkan usaha menjaga kesehatan. Sementara perilaku yang baik ditunjukkan dengan mencuci tangan dengan air dan sabun, memakai masker, tidak melakukan kontak langsung dengan orang yang sakit, mengkonsumsi vitamin, olah raga rutin, berdoa, lebih sering konsumsi makanan bergizi dan minum air putih, konsumsi sayur dan buah, menghindari keramaian, melakukan social distancing, dan tetap di rumah jika tidak ada urusan yang mendesak untuk keluar rumah [4].

Berdasarkan penjelasan tersebut dapat kita lihat bahwa pengetahuan, sikap dan perilaku sangat penting dalam pencegahan COVID-19 sehingga peneliti tertarik melakukan literature review : gambaran pengetahuan, sikap dan perilaku masyarakat tentang COVID-19.

\section{Metode}

Desain penelitian ini adalah literature review. Pencarian artikel publikasi dilakukan dengan cara mengakses basis data Pubmed, DOAJ, Garuda dan Google Scholar menggunakan kata kunci "knowledge COVID-19", "attitude COVID-19" dan "practice COVID-19" untuk jurnal internasional atau berbahasa inggris. Sedangkan pencarian jurnal nasional atau berbahasa indonesia menggunakan kata kunci "pengetahuan tentang COVID-19", sikap tentang COVID-19" dan "perilaku tentang COVID-19". 


\section{Prosiding Seminar Nasional Kesehatan Lembaga Penelitian dan Pengabdian Masyarakat Universitas Muhammadiyah Pekajangan Pekalongan}

Telaah kritis (Critical Appraisal) artikel dilakukan menggunakan Discern Instrument yang berfungsi untuk membantu mengevaluasi reliabilitas dan kualitas informasi kesehatan [6]. Kriteria inklusi artikel yang dibahas adalah sesuai dengan kata kunci pencarian, dipublikasikan pada tahun 2020-2021, memiliki komponen naskah standar atau teks lengkap, memiliki tujuan untuk mendeskripsikan gambaran pengetahuan, sikap dan perilaku masyarakat tentang COVID-19 dan terindeks sinta atau scopus. Sedangkan kriteria eksklusinya adalah naskah konferensi, surat ke editorial, dan penelitian kualitatif.

\section{Hasil dan Pembahasan \\ Proses Seleksi Artikel}

Proses seleksi artikel dijelaskan dalam gambar berikut :

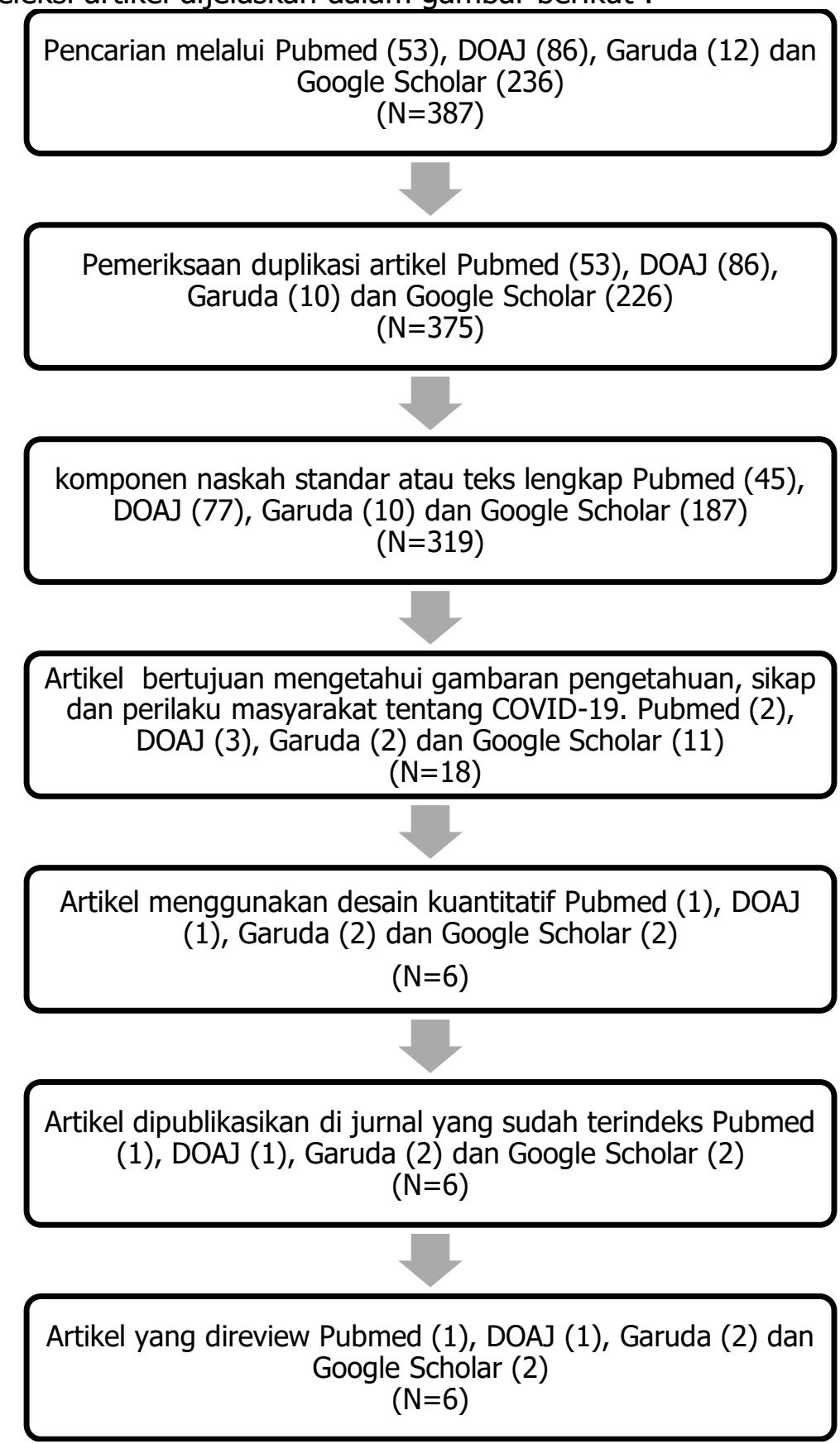

Gambar 1. Proses Seleksi Artikel 


\section{Prosiding Seminar Nasional Kesehatan Lembaga Penelitian dan Pengabdian Masyarakat Universitas Muhammadiyah Pekajangan Pekalongan}

\section{Hasil}

Tabel 1. Distribusi Frekuensi Pengetahuan Responden

\begin{tabular}{|c|c|c|c|c|c|c|c|}
\hline \multirow[t]{3}{*}{ Penulis } & \multicolumn{6}{|c|}{ Pengetahuan } & \multirow{3}{*}{$\begin{array}{l}\text { Jumlah } \\
\text { Responden }\end{array}$} \\
\hline & \multicolumn{2}{|c|}{ Baik } & \multicolumn{2}{|c|}{ Cukup } & \multicolumn{2}{|c|}{ Kurang } & \\
\hline & $\mathrm{F}$ & $\%$ & $\mathrm{~F}$ & $\%$ & $\mathrm{~F}$ & $\%$ & \\
\hline Yanti et al., (2020) & 1.096 & 99,00 & 6 & 1,00 & 0 & 0,00 & 1.102 \\
\hline Utami et al., (2020) & 847 & 83,00 & 0 & 0,00 & 174 & 17,00 & 1.021 \\
\hline Taghrir et al., (2020) & 209 & 86,96 & 0 & 0,00 & 31 & 13,04 & 240 \\
\hline Afzal et al., (2020) & 502 & 50,00 & 0 & 0,00 & 502 & 50,00 & 1.004 \\
\hline Roy et al., (2020) & \multicolumn{4}{|c|}{ Tidak Menyebutkan } & & & 662 \\
\hline Total Responden & 2.654 & 78,82 & 6 & 0,18 & 707 & 21,00 & 4.029 \\
\hline
\end{tabular}

Tabel 2. Rata-rata Pengetahuan Responden

\begin{tabular}{cccc}
\hline Penulis & Mean Pengetahuan & Range Pengetahuan & Jumlah Responden \\
\hline Zhong et al., (2020) & 10,8 & $0-12$ & 6.910 \\
\hline
\end{tabular}

Tabel 1 menunjukkan pada penelitian Yanti et al., (2020), Utami et al., (2020), Taghrir et al., (2020), dan Afzal et al., (2020) mayoritas responden memiliki pengetahuan yang baik [7]-[10]. Sedangkan tabel 2 menunjukkan pada penelitian Zhong et al., (2020) rata-rata skor pengetahuan responden sebesar 10,8 dengan kemungkinan skor 0-12 [12].

Tabel 3. Distribusi Frekuensi Sikap Responden

\begin{tabular}{lrrrrr}
\hline \multirow{2}{*}{ Penulis } & \multicolumn{4}{c}{ Sikap } & \multirow{2}{*}{$\begin{array}{c}\text { Jumlah } \\
\text { Responden }\end{array}$} \\
\cline { 2 - 5 } & \multicolumn{2}{c}{ Baik } & \multicolumn{2}{c}{ Kurang } & \\
\cline { 2 - 5 } & $\mathrm{F}$ & $\%$ & $\mathrm{~F}$ & $\%$ & \\
\hline Yanti et al., (2020) & 646 & 59,00 & 456 & 41,00 & 1.102 \\
Utami et al., (2020) & 722 & 70,70 & 299 & 29,30 & 1.021 \\
Afzal et al., (2020) & 753 & 75,00 & 251 & 25,00 & 1.004 \\
Roy et al., (2020) & 498 & 75,30 & 164 & 24,70 & 662 \\
Zhong et al., (2020) & 6.274 & 90,80 & 636 & 9,20 & 6.910 \\
Taghrir et al., (2020) & & \multicolumn{2}{c}{ Tidak Menyebutkan } & & 240 \\
\hline Total Responden & 8.893 & 83,12 & 1.806 & 16,88 & 10.939 \\
\hline
\end{tabular}

Tabel di atas menunjukkan mayoritas responden mempunyai sikap yang baik [7], [8], [10]-[12].

Tabel 4. Distribusi Frekuensi Perilaku Responden

\begin{tabular}{lrrrrr}
\hline \multirow{1}{*}{ Penulis } & \multicolumn{3}{c}{ Perilaku } & \multicolumn{2}{c}{$\begin{array}{c}\text { Jumlah } \\
\text { Responden }\end{array}$} \\
\cline { 2 - 5 } & \multicolumn{2}{c}{ Baik } & \multicolumn{2}{c}{ Kurang } & \\
\cline { 2 - 5 } & $\mathrm{F}$ & $\%$ & $\mathrm{~F}$ & $\%$ & \\
\hline Yanti et al., (2020) & 1.029 & 93,00 & 73 & 7,00 & 1.102 \\
Utami et al., (2020) & 718 & 70,30 & 303 & 29,70 & 1.021 \\
Taghrir et al., (2020) & 227 & 94,47 & 13 & 5,53 & 240 \\
Afzal et al., (2020) & 669 & 66,66 & 335 & 34,44 & 1.004 \\
Zhong et al., (2020) & 6.553 & 94,83 & 357 & 5,17 & 6910 \\
Roy et al., (2020) & \multicolumn{3}{c}{ Tidak Menyebutkan } \\
\hline Total Responden & 9.196 & 89,48 & 1.081 & 10,52 & 10.939 \\
\hline
\end{tabular}

Tabel di atas menunjukkan mayoritas responden mempunyai perilaku yang baik [7]-[10], [12]. 


\section{Prosiding Seminar Nasional Kesehatan 2021 Lembaga Penelitian dan Pengabdian Masyarakat Universitas Muhammadiyah Pekajangan Pekalongan}

\section{Pembahasan}

\section{Pengetahuan}

Pengetahuan merupakan hasil tahu yang terjadi setelah orang melakukan penginderaan terhadap suatu objek tertentu. Pengetahuan atau kognitif merupakan domain yang sangat penting untuk terbentuknya tindakan seseorang (overt behavior). Pengetahuan didapatkan seseorang melalui panca indranya, yaitu melalui melihat, merasa, mendengar, meraba, dan mencium. Pengetahuan merupakan salah satu hal yang penting untuk menentukan tindakan seseorang [3].

Berdasarkan penelitian yang dibahas menunjukkan mayoritas responden mempunyai pengetahuan yang baik tentang COVID-19. Hal ini sejalan dengan penelitian Purnamasari \& Raharyani (2020) yang menyebutkan bahwa tingkat pengetahuan masyarakat tentang COVID-19 berada pada kategori tinggi [13]. Pengetahuan masyarakat tentang COVID-19 merupakan aspek yang sangat penting dalam masa pandemi seperti sekarang ini, yang meliputi penyebab COVID-19 dan karakteristik virusnya, tanda dan gejala, istilah yang terkait, pemeriksaan yang diperlukan dan proses transmisi serta upaya pencegahan penyakit tersebut [13]. Pengetahuan yang baik dapat didukung oleh penerimaan terhadap informasi yang beredar di masyarakat tentang COVID-19 [14].

Pengetahuan yang diteliti oleh Utami et al., (2020) adalah pemahaman akan proses penularan penyakit, informasi terkait pencegahan yang dapat dilakukan, dan informasi tentang sebaran kasus [8]. Taghrir et al., (2020) meneliti tingkat pengetahuan responden menggunakan beberapa item pertanyaan tentang pengertian, epidemiologi, tanda dan gejala, masa inkubasi virus, diagnosis, cara penularan, cara pencegahan, dan pengobatan [9].

Afzal et al., (2020) menggunakan tujuh parameter dalam menggali pengetahuan responden yaitu mengetahui wabah virus, mengetahui tentang pandemi COVID-19, mengetahui transmisi manusia ke manusia, melihat pasien COVID-19, Pergi ke kolam renang umum dalam 15 hari terakhir, bertemu dengan orang yang baru pulang dari luar negeri, dan mengetahui bahwa kontak fisik adalah sumber utama penularan COVID-19 [10]. Sedangkan Zhong et al., (2020) menanyakan tentang tanda gejala, pengobatan, prognosis, cara penularan, cara pencegahan dan penularan COVID-19 [12].

Pengetahuan adalah kesadaran diri manusia yang diperoleh langsung dari kehidupan. Pengetahuan individu berasal dari proses pembelajaran sikap dan perilaku melalui proses belajar mengajar yang dipengaruhi oleh tingkat pendidikan individu atau komunitasnya dan termasuk masukan dari media yang dirancang untuk memberikan informasi kepada publik [7]. Pengetahuan sangat penting dalam melanjutkan aspek sikap dan perilaku karena jika seserang tidak tahu maka tidak akan ada tindakan nyata yang dilakukan. Pengetahuan masyarakat dalam mencegah transmisi penyakit akan menekan penularan COVID-19 lebih lanjut [15].

Al-hanawi et al., (2020) menjelaskan bahwa prediktor signifikan pengetahuan masyarakat tentang COVID-19 adalah usia, jenis kelamin, tingkat pendidikan, dan tingkat pendapatan. Responden yang lebih tua, perempuan, dan berpendidikan tinggi lebih berpengetahuan tentang penyakit menular yang muncul [16]. Al-hanawi et al., 


\section{Prosiding Seminar Nasional Kesehatan Lembaga Penelitian dan Pengabdian Masyarakat Universitas Muhammadiyah Pekajangan Pekalongan}

(2020) juga menemukan bahwa masyarakat yang berpenghasilan tinggi lebih mengetahui tentang COVID-19 [16].

Tingginya tingkat pengetahuan responden tentang COVID-19 berkorelasi dengan tingginya tingkat pendidikan responden. semakin tinggi tingkat pendidikan seseorang maka semakin tinggi pula pengetahuan [12], [13]. Selain itu responden secara aktif mempelajari pengetahuan tentang COVID -19 dari berbagai saluran informasi seperti televisi, situs resmi otoritas kesehatan setempat, dan akun media sosial resmi otoritas kesehatan setempat [12]. Individu yang memiliki informasi akan dapat menentukan bagaimana bereaksi dan mengambil keputusan ketika menghadapi suatu masalah [7].

Pengetahuan masyarakat tentang COVID-19 merupakan aspek yang sangat penting dalam masa pandemi seperti sekarang ini, yang meliputi penyebab COVID-19 dan karakteristik virusnya, tanda dan gejala, istilah yang terkait dengan COVID-19, pemeriksaan yang diperlukan dan proses transmisi serta upaya pencegahan penyakit tersebut. Pengetahuan masyarakat yang tinggi tentang COVID-19 berpengaruh terhadap kejadian dan pencegahan penyakit COVID-19. Pengetahuan yang baik dapat didukung oleh penerimaan terhadap informasi yang beredar di masyarakat tentang COVID-19.

\section{Sikap}

Sikap menggambarkan suka atau tidak suka seseorang terhadap suatu objek. Sikap sering diperoleh dari pengalaman sendiri atau dari orang lain yang paling dekat. Sikap membuat seseorang mendekati atau menjauhi orang lain maupun objek lain [3]. Sikap manusia merupakan prediktor perilaku, meskipun faktor lain seperti lingkungan dan kepercayaan diri dapat mempengaruhinya. Artinya sikap akan menentukan tindakan, namun terkadang sikap tidak tercermin dalam tindakan. Pertimbangan apakah sesuatu itu baik atau buruk akan berdampak pada tindakan pribadi [7].

Berdasarkan penelitian yang dibahas menunjukkan mayoritas responden mempunyai sikap yang baik tentang COVID-19. Hal ini sesuai dengan penelitian Alhanawi et al., (2020) yang menyebutkan bahwa mayoritas responden menunjukkan sikap positif dan optimis terhadap COVID-19. Sikap positif dan keyakinan yang tinggi dalam pengendalian COVID-19 dapat dijelaskan dengan tindakan pemerintah yang belum pernah terjadi sebelumnya dan respons yang cepat dalam mengambil tindakan pengendalian dan pencegahan yang ketat terhadap COVID-19, untuk melindungi warga negara dan memastikan kesejahteraan mereka [16].

Sikap yang diteliti oleh Utami et al., (2020) meliputi keinginan dalam melakukan pencegahan, sikap positif terhadap relasi/keluarga/rekan yang telah terkena COVID-19 [8]. Afzal et al., (2020) menggunakan sembilan belas parameter dalam menggali sikap responden. Sikap dinilai dengan menanyakan tentang persetujuan responden tentang pasien yang terinfeksi harus dipisahkan, pemeriksaan penyakit, pengobatan gratis, karantina jika terinfeksi, pergi ke masjid sebagai faktor penyebaran infeksi, kesehatan orang lain di sekitar mereka terkait dengan kesehatan mereka, acara publik harus dilarang, stabilitas ekonomi bisa meningkatkan kondisi kesehatan, kebutuhan masker dan pembersih tangan, fasilitas perawatan, dan kampanye vaksinasi, penangguhan penerbangan internasional, dan penutupan fasilitas publik [10]. 


\section{Prosiding Seminar Nasional Kesehatan 2021 Lembaga Penelitian dan Pengabdian Masyarakat Universitas Muhammadiyah Pekajangan Pekalongan}

Roy et al., (2020) meneliti sikap responden dengan menanyakan persetujuan responden terhadap upaya-upaya pencegahan dan penularan COVID-9, yang meliputi mengarantina / mengisolasi diri jika mengalami demam dan batuk, sociai distancing, bepergian di dalam negeri agar aman selama pandemi, pasien dapat sembuh dari infeksi COVID-19, dan penderita seharusnya tidak diizinkan untuk tinggal dalam komunitas saat ini [11]. Sedangkan Zhong et al., (2020) menanyakan persetujuan responden tentang kemungkinan negara (tiongkok) dalam mengontrol dan memenangkan pertarungan dengan COVID-19 [12].

Berbagai faktor dapat mempengaruhi sikap, misalnya pengetahuan, pengalaman pribadi, budaya, informasi, lembaga pendidikan atau lembaga keagamaan, serta faktor emosional dalam diri individu. Perubahan sikap terjadi ketika data dapat dipahami, diterima, dan disetujui [7]. Baik dan positifnya sikap responden dapat dipengaruhi oleh pengetahuan yang baik [10]. Pengetahuan memiliki peran penting dalam mendefinisikan dan meningkatkan sikap. artinya, pengetahuan yang baik akan membangun sikap yang positif atau baik pula [7].

Pembentukan sikap juga melalui proses interaksi sosial. Melalui interaksi sosial, individu menampilkan sikap tertentu terhadap objek psikologis yang ditemui [7]. Sikap masyarakat yang baik akan dilaksanakan dengan konsisten bila ada aturan yang tegas dari pemangku kebijakan dan role model yang baik dari tokoh-tokoh publik. Sehingga penting dalam membentuk sikap masyarakat yang didukung oleh kebijakan pemerintah [17].

\section{Perilaku}

Perilaku adalah segala kegiatan atau aktivitas yang dilakukan seseorang, sebagai reaksi atau respons terhadap stimulus dari luar, yang menggambarkan pengetahuan dan sikap mereka [3]. Perilaku mengacu pada tindakan dan refleksi pribadi yang dihasilkan oleh sinkronisasi sistem anatomi, fisiologis, dan psikologis [18].

Berdasarkan penelitian yang dibahas menunjukkan mayoritas responden mempunyai perilaku yang baik. Hasil penelitian ini sejalan dengan penelitian Purnamasari \& Raharyani (2020) yang menunjukkan mayoritas masyarakat mempunyai perilaku yang baik terkait COVID-19. Perilaku yang baik ditunjukkan dengan kepatuhan dalam memakai masker saat bepergian atau beraktivitas di luar rumah, mencuci tangan dengan sabun atau hand sanitizer secara sering, menghindari kerumunan dan physical distancing atau menjaga jarak.

Perilaku yang diteliti oleh Utami et al., (2020) meliputi perilaku responden akan protokol new normal seperti konsistensi penggunaan masker, menahan diri untuk tidak keluar rumah kecuali jika terpaksa, selalu mencuci tangan dengan sabun di air mengalir, selalu menyediakan disinfektan, mandi sesegera mungkin setelah keluar dari rumah, tidak melakukan kontak fisik, menjaga jarak, membatasi jumlah penumpang dalam kendaraan, menjaga sistem kekebalan tubuh melalui asupan nutrisi yang adekuat dan olahraga rutin. Keterampilan juga meliputi secara periodik mencari informasi terkait update kasus COVID-19 [8].

Afzal et al., (2020) menggunakan sebelas parameter dalam menggali perilaku responden yang meliputi kontak dengan orang tak dikenal, kontak dengan orang dengan riwayat perjalanan dari luar negeri, sering mencuci tangan, menutupi wajah 


\section{Prosiding Seminar Nasional Kesehatan Lembaga Penelitian dan Pengabdian Masyarakat Universitas Muhammadiyah Pekajangan Pekalongan}

saat bersin atau batuk, merokok, pergi ke masjid, serta mempraktikkan menjaga jarak fisik yang aman [10]. Sedangkan Zhong et al., (2020) menanyakan tentang apakah responden pergi ke tempat keramaian dan apakah responden mengenakan masker saat keluar rumah [12].

Taghrir et al., (2020) menilai perilaku dengan sembilan item pertanyaan yang terdiri dari lima item tentang mengurangi penggunaan tempat umum dalam kehidupan sehari-hari, satu item tentang perilaku pencegahan selama batuk, dua item tentang mencuci tangan secara intensif dan desinfeksi permukaan dan item terakhir tentang berbicara dengan orang terdekat tentang pencegahan [9].

Ada tiga domain yang berhubungan dengan perilaku manusia, yaitu domain kognitif, afektif, dan konatif. Unsur tingkah laku terdiri dari pengetahuan (kognitif) dan sikap (afektif), tingkah laku (psikomotor) dan tindakan nyata (tindakan). Keragaman pola perilaku dan proses kemunculannya penting bagi semua individu, dan dapat dipengaruhi oleh tekanan, motivasi, dan dukungan eksternal [18].

Baiknya perilaku responden dapat disebabkan oleh tingginya tingkat pendidikan, pengetahuan dan sikap yang baik. menurut Utami et al., (2020) perilaku kesehatan dipengaruhi oleh banyak faktor, diantaranya pengetahuan, persepsi, emosi, motivasi, dan lingkungan [8]. Pengetahuan merupakan domain yang sangat penting untuk pembentukan perilaku individu. Pengetahuan tentang pencegahan dan penularan COVID-19 akan mendasari sikap untuk mengambil tindakan pencegahan dan mempengaruhi perilaku [7].

Perilaku yang baik dapat menjadi upaya pencegahan terhadap penularan berbagai macam penyakit [19]. Cara terbaik untuk mencegah COVID-19 adalah dengan memutus mata rantai penyebaran COVID-19 melalui isolasi, deteksi dini dan melakukan proteksi dasar yaitu melindungi diri dan orang lain dengan cara sering mencuci tangan dengan air mengalir dan sabun atau menggunakan hand sanitizer, menggunakan masker dan tidak menyentuh area muka sebelum mencuci tangan, serta menerapkan etika batuk dan bersin dengan baik [2].

\section{Kesimpulan}

Mayoritas responden mempunyai pengetahuan yang baik (80\%), sikap yang baik (70\%) dan perilaku yang baik (90\%) tentang COVID-19. pengetahuan yang baik ditunjukkan dengan mampu menjawab pertanyaan tentang pengertian, tanda dan gejala, masa inkubasi virus, diagnosis, cara penularan, cara pencegahan, dan pengobatan COVID-19. Sikap yang baik ditunjukkan dengan persetujuan responden tentang isolasi pasien COVID-19, pemeriksaan penyakit, pengobatan gratis, pergi ke masjid sebagai faktor penyebaran infeksi, kesehatan antar orang sangat terkait, acara publik harus dilarang, kebutuhan masker dan pembersih tangan, fasilitas perawatan, vaksinasi, penangguhan penerbangan internasional, dan penutupan fasilitas publik. Perilaku yang baik ditunjukkan dengan konsistensi penggunaan masker, menahan diri untuk tidak keluar rumah kecuali jika terpaksa, selalu mencuci tangan dengan sabun dan air mengalir, selalu menyediakan disinfektan, mandi sesegera mungkin setelah keluar dari rumah, tidak melakukan kontak fisik, menjaga jarak, membatasi jumlah penumpang dalam kendaraan, menjaga sistem kekebalan tubuh melalui asupan nutrisi yang adekuat dan olahraga rutin. 


\section{Prosiding Seminar Nasional Kesehatan $\mathbf{2 0 2 1}$ \\ Lembaga Penelitian dan Pengabdian Masyarakat Universitas Muhammadiyah Pekajangan Pekalongan}

\section{Referensi}

[1] Y. Han and H. Yang, "The transmission and diagnosis of 2019 novel coronavirus infection disease (COVID-19): A Chinese perspective," J Med Virol, 2020, doi: $10.1002 /$ jmv.25749.

[2] Kemenkes RI, PEDOMAN PENCEGAHAN DAN PENGENDALIAN CORONAVIRUS DISESASE (COVID-19). Jakarta: Kemenkes RI, 2020.

[3] S. Notoatmodjo, IImu Perilaku Kesehatan. Jakarta: Rineka Cipta, 2016.

[4] J. Moudy and R. A. Syakurah, "Pengetahuan terkait Usaha Pencegahan Coronavirus Disease (COVID-19) di Indonesia," HIGEIA J. PUBLIC Heal. Res. Dev., vol. 4, no. 3, pp. 333-346, 2020.

[5] A. Erfani, R. Shahriarirad, K. Ranjbar, A. Mirahmadizadeh, and M. Moghadami, "Title: Knowledge, Attitude and Practice toward the Novel Coronavirus ( COVID19 ) Outbreak: A Population-Based Survey in Iran," Bull World Heal. Organ, no. March, 2020, doi: http://dx.doi.org/10.2471/BLT.20.256651.

[6] D. Charnock, S. Shepperd, G. Needham, and R. Gann, "DISCERN: An instrument for judging the quality of written consumer health information on treatment choices," J. Epidemiol. Community Health, vol. 53, no. 2, pp. 105-111, 1999, doi: 10.1136/jech.53.2.105.

[7] B. Yanti et al., "Community Knowledge, Attitudes, and Behavior Towards Social Distancing Policy As Prevention Transmission of Covid-19 in Indonesia," J. Adm. Kesehat. Indones., vol. 8, no. 2, p. 4, 2020, doi: 10.20473/jaki.v8i2.2020.4-14.

[8] R. A. Utami, R. E. Mose, and M. Martini, "Pengetahuan, Sikap dan Keterampilan Masyarakat dalam Pencegahan COVID-19 di DKI Jakarta," J. Kesehat. Holist., vol. 4, no. 2, pp. 68-77, 2020, doi: 10.33377/jkh.v4i2.85.

[9] M. H. Taghrir, R. Borazjani, and R. Shiraly, "COVID-19 and iranian medical students; A survey on their related-knowledge, preventive behaviors and risk perception," Arch. Iran. Med., vol. 23, no. 4, pp. 249-254, 2020, doi: 10.34172/aim.2020.06.

[10] M. S. Afzal et al., "Community-Based Assessment of Knowledge, Attitude, Practices and Risk Factors Regarding COVID-19 Among Pakistanis Residents During a Recent Outbreak: A Cross-Sectional Survey," J. Community Health, 2020, doi: 10.1007/s10900-020-00875-z.

[11] D. Roy, S. Tripathy, S. K. Kar, N. Sharma, S. K. Verma, and V. Kaushal, "Study of knowledge, attitude, anxiety \& perceived mental healthcare need in Indian population during COVID-19 pandemic," Asian J. Psychiatr., vol. 51, no. April, p. 102083, 2020, doi: 10.1016/j.ajp.2020.102083.

[12] B. L. Zhong et al., "Knowledge, attitudes, and practices towards COVID-19 among chinese residents during the rapid rise period of the COVID-19 outbreak: A quick online cross-sectional survey," Int. J. Biol. Sci., vol. 16, no. 10, pp. 17451752, 2020, doi: 10.7150/ijbs.45221.

[13] I. Purnamasari and A. E. Raharyani, "Tingkat Pengetahuan dan Perilaku Masyarakat Kabupaten Wonosobo tentang COVID-19," J. IIm. Kesehat., vol. 10, no. 1, pp. 34-39, 2020, doi: 10.14421/lijid.v3i1.2224.

[14] T. Sulistyaningtyas, J. Jaelani, and Y. Suryani, "Informasi Wabah Virus Covid-19: Kuasa Pengetahuan dan Kelas Sosial," Institut Teknologi Bandung, 2020. 


\section{Prosiding Seminar Nasional Kesehatan $\mid 2021$ Lembaga Penelitian dan Pengabdian Masyarakat Universitas Muhammadiyah Pekajangan Pekalongan}

[Online]. Available: http://sinta.ristekbrin.go.id/covid/penelitian/detail/80. [Accessed: 09-Aug-2021].

[15] S. Law, A. W. Leung, and C. Xu, "Severe acute respiratory syndrome (SARS) and coronavirus disease-2019 (COVID-19): From causes to preventions in Hong Kong," Int. J. Infect. Dis., vol. 94, pp. 156-163, 2020, doi: 10.1016/j.ijid.2020.03.059.

[16] M. K. Al-hanawi et al., "Knowledge, Attitude and Practice Toward COVID-19 Among the Public in the Kingdom of Saudi Arabia: A Cross-Sectional Study," Front. Public Heal., vol. 8, no. May, pp. 1-10, 2020, doi: 10.3389/fpubh.2020.00217.

[17] A. A. Firda and S. Haksama, "Building Health System Resilience During Covid-19 Crisis," J. Adm. Kesehat. Indones., vol. 8, no. 2, p. 1, 2020, doi: 10.20473/jaki.v8i2.2020.1-3.

[18] K. A. Pawelek, C. Salmeron, and S. De Valle, "Connecting within and betweenhosts dynamics in the influenza infection-staged epidemiological models with behavior change," J. Coupled Syst. Multiscale Dyn., vol. 3, no. 3, pp. 233-243, 2015, doi: https://doi.org/10.1166/jcsmd.2015.1082.

[19] A. O. A. W. Lestari, "Hubungan Pengetahuan Dan Sikap Terhadap Perilaku Cuci Tangan Pada Masyarakat Kelurahan Pegirian," J. PROMKES, vol. 7, no. 1, p. 1, 2019, doi: 10.20473/jpk.v7.i1.2019.1-11. 